\title{
Depth-dependent nutritional condition of sprat Sprattus sprattus larvae in the central Bornholm Basin, Baltic Sea
}

\author{
Andreas Dänhardt ${ }^{1,3, *}$, Myron A. Peck ${ }^{1}$, Catriona Clemmesen ${ }^{2}$, Axel Temming ${ }^{1}$ \\ ${ }^{1}$ Institute of Marine Ecosystems and Fisheries Science, University of Hamburg, Olbersweg 24, 22767 Hamburg, Germany \\ ${ }^{2}$ Leibniz-Institute of Marine Sciences at Kiel University (IFM-GEOMAR), Düsternbrooker Weg 20, 24105 Kiel, Germany
}

${ }^{3}$ Present address: Institute of Avian Research, c/o Research Center Terramare, Schleusenstrasse 1, 26382 Wilhelmshaven, Germany

\begin{abstract}
Bimodal depth distribution patterns observed for sprat Sprattus sprattus larvae in previous field studies conducted in the deep basins of the Baltic Sea have led researchers to hypothesise that larval sprat condition was depth-dependent. We examined this hypothesis by measuring morphological, biochemical and otolith-based proxies for nutritional condition in sprat larvae collected in discrete $5 \mathrm{~m}$ depth intervals from the surface to the bottom in the central Bornholm Basin. Similar to earlier studies, larval sprat were most abundant in 2 depth strata (0 to 10 and 65 to $75 \mathrm{~m}$ ). Their nutritional condition in surface and deep waters was not uniformly expressed by the different indices. For example, sprat larvae from 0 to $10 \mathrm{~m}$ could not be distinguished from conspecifics caught at 65 to $75 \mathrm{~m}$ by a long-latency condition proxy (otolith-based growth rates). Similarly, a mediumlatency proxy (RNA:DNA) did not suggest differences in condition between the depths. However, short-latency proxies (protein:standard length and DNA:dry weight) supported the depth-dependent condition hypothesis. The lack of correspondence and pitfalls associated with the use and interpretation of multiple condition indices (e.g. the influences of temperature and body size) are discussed and recommendations to strengthen these various metrics are provided.
\end{abstract}

KEY WORDS: Sprattus sprattus $\cdot$ Larvae $\cdot$ Baltic $\cdot$ Survival $\cdot$ Growth $\cdot$ Condition $\cdot$ RNA:DNA $\cdot$ Protein

\section{INTRODUCTION}

Early in life, marine fish often suffer high mortality rates, and subtle changes therein can contribute to 10 -fold or higher fluctuations in year-class strength (Houde 1987). Rates of growth and survival can be positively correlated in the early life stages of a number of marine fish species (Houde 1987, Cowan \& Shaw 2002), and are affected by an amalgam of factors (e.g. starvation, suboptimal hydrographic conditions, predation and disease) that vary within a season and between years. Batches of sub-cohorts can be produced on short time scales (days to weeks) and experience different environmental conditions in the course of a spawning season, making each sub-cohort's contribu- tion to overall year-class strength highly variable. Survivors probably originate from larval batches that have encountered environments favourable to fast growth early in life (Cushing 1974). Understanding the spatio-temporal dynamics of unfavourable environments (i.e. environments correlated with reduced growth rates that cause prolonged durations of developmental stages particularly vulnerable to mortality via starvation and predation: see Houde 1987), may increase our ability to predict survival of early life stages of marine fish.

In the Baltic Sea, the sprat Sprattus sprattus plays a key trophodynamic role as a prey resource (Nissling 2004) for a number of species (including cod Gadus morhua and harbour porpoise Phocoena phocoena) 
and as a predator on both zooplankton and fish eggs (Arrhenius \& Hansson 1993, Köster \& Möllmann 2000). It is also an economically valuable species being, at the present time, the most important target of commercial exploitation (ICES 2004). The growth and survival of larval and early juvenile stages have been identified as the main determinants of recruitment variability in populations of sprat and cod inhabiting the Baltic Sea (Köster et al. 2003).

One of the most distinctive characteristics of the Baltic Sea is the permanent water column stratification, producing gradients in temperature, salinity, $\mathrm{O}_{2}$ concentration and secondary production that can become particularly strong during spring and summer (Matthäus \& Nausch 2001). This vertical variability in environmental conditions creates areas supportive of, as well as obstructive to, fast growth and high survival rates of larval fish. Temperature in particular has been discovered to be a key factor of sprat survival and recruitment (MacKenzie \& Köster 2004). In the Baltic, survival chances may increase for larval fish that are able to distribute themselves in favourable strata of the water column. Interestingly, in sprat larvae, a bimodal depth distribution is often encountered in the Baltic basins with high concentrations of larvae close to the surface and near the seafloor. Larvae in deeper waters are often smaller, possibly suggesting that larval sprat growth and condition may be depth-dependent (Wieland \& Zuzarte 1991).

In the present study, we compared the nutritional condition and growth rate of sprat larvae encountered near the surface $(0$ to $10 \mathrm{~m})$ and bottom (65 to $75 \mathrm{~m}$ ). Our hypothesis $\left(H_{0}\right)$ was that the condition of larval sprat during the summer was similar near the surface and close to the seafloor in one of the most important spawning grounds for this species in the Baltic-the Bornholm Basin (Köster et al. 2001). Several condition indices were used: a morphometric condition factor (CF) (e.g. Hempel \& Blaxter 1963), RNA:DNA (Buckley 1984, Clemmesen 1994), the daily protein growth rate Gp (Buckley 1984), DNA per unit freeze-dried weight (DW) (Bulow 1987), protein content (Ehrlich 1974, Buckley 1979, Clemmesen 1987) per unit standard length (SL), and the mean daily somatic growth rate based on otolith microstructure analysis (Fossum et al. 2000, Belchier et al. 2004). These various condition proxies are commonly used (e.g. Bulow 1987, Rè \& Gonçalves 1993, Bergeron \& Boulhic 1994, Clemmesen 1994, Ferron \& Leggett 1994, Belchier et al. 2004) but rarely examined and compared in the same study. Therefore, the present work also attempted to evaluate whether larval condition would be expressed uniformly when multiple measures were performed on the same individual or on individuals from the same larval sub-cohort.

\section{MATERIALS AND METHODS}

Field sampling. Samples of fish larvae and zooplankton were obtained using a BIOMOC sampler, a modified 'MOCNESS' system (Wieland \& Jarre-Teichmann 1997), deployed on 9 and 10 July 2000 from the RV 'Alkor' at 1 station in the central Bornholm Basin,

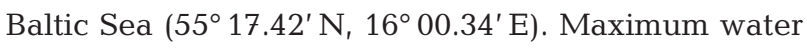
depth at this station was $80 \mathrm{~m}$. The BIOMOC was equipped with 9 nets each with a mouth opening of $1 \mathrm{~m}^{2}$ and a mesh size of $330 \mu \mathrm{m}$ with a microzooplankton liner (mesh size $50 \mu \mathrm{m}$ ) fitted into every other net opening. Over a $24 \mathrm{~h}$ period the whole water column was sampled every $3 \mathrm{~h}$ in 2 consecutive hauls. The first haul sampled $5 \mathrm{~m}$ depth intervals between 0 and $40 \mathrm{~m}$ mid-stratum (i.e. $2-3,7-8,12-13, \ldots$ $37-38 \mathrm{~m}$ ) and the second haul sampled between 45 and $75 \mathrm{~m}$ mid-stratum (i.e. $42-43,47-48,52-53 \ldots$ 72-73 m). Due to ship movements, the exact hauldepths could not be determined and were thus given as ranges (i.e. $0-5 \mathrm{~m}, 5-10 \mathrm{~m}, \ldots$ ) A total of 16 hauls was conducted, so that the complete water depth was covered 8 times (see Figs. 2 \& 4).

The gear was towed horizontally at a speed of 3 knots. Each net was kept open for 3 to $5 \mathrm{~min}$. The filtered water volume was calculated by multiplying the area of the net opening by the distance towed as tracked by an on-board GPS device. A vertical profile of temperature, salinity, pressure, oxygen and chlorophyll a was obtained using a CTD cast. Water density was calculated from temperature, salinity and pressure (Fofonoff 1985) and the maximum change in density within a $5 \mathrm{~m}$ depth interval was calculated to evaluate the degree of stratification (Coombs et al. 1992).

At the completion of each haul, the nets were carefully rinsed and sprat larvae were removed and preserved in a $4 \%$ buffered formaldehyde/seawater solution within $15 \mathrm{~min}$. In the laboratory the solution was replaced with a formaldehyde-free preservation fluid (Steedman 1976) prior to analysis. Immediately after recovery from the nets, subsamples of sprat larvae (total $n=127$ ) were randomly selected across hauls and stored in liquid nitrogen for biochemical and otolith microstructure analyses.

Gut contents were examined under a stereomicroscope (Leica MZ 16) and identified to the lowest possible taxonomic level.

Zooplankton samples were preserved as described above for the sprat larvae, determined to the lowest possible taxonomic level, and counted in a Bogoroff tray under a stereomicroscope (Leica MZ 16). Where necessary, subsamples were taken using a plankton splitter.

Morphological measurements. SL $( \pm 0.5 \mathrm{~mm}$, stereomicroscope Leica MZ 16 with object micrometer) and DW $( \pm 0.1 \mu \mathrm{g}$, Christ Alpha freeze-drier, Sartorius 
microbalance SE2-0CE) of all individuals captured ( $n=1121$ ) were measured. Values were not corrected for larval shrinkage induced by sampling and preservation. In order to ensure comparability among specimens and depth ranges, larvae of a size spectrum that was adequately represented in both shallow and deep samples (>20 $\mu \mathrm{g}$ DW and between 8 and $12 \mathrm{~mm} \mathrm{SL),}$ were divided into 1-mm standard length-classes. Only larvae of the same length-classes were compared.

Many larvae were damaged during catch (e.g. eyes and/or intestines lost). The degree of damage may influence the proxies measured and is quantitatively assessed elsewhere (A. Dänhardt \& A. Temming unpubl.). For the present study, we compared only larvae with similar degrees of damage between depths.

The relationship between DW and SL was determined from:

$$
\log \mathrm{DW}=\log \mathrm{a}+\mathrm{b}(\log \mathrm{SL})
$$

for individuals from both depth strata combined, where DW $=\mathrm{mg}, \mathrm{SL}=\mathrm{mm}$, and $\mathrm{a}$ and $\mathrm{b}$ are constants.

A morphometric condition factor $(\mathrm{CF})$, a normalised measure of body weight-at-length (Hempel \& Blaxter 1963) was then calculated as:

$$
\mathrm{CF}=100000 \mathrm{DW} \mathrm{SL}^{-\mathrm{b}}
$$

A decrease in DW (and thus in CF) is expected within a few hours of starvation (Ferron \& Leggett 1994). In order to exclude size effects on CF (Peck et al. 2005), the comparisons between deep and surface strata were confined to the same length range of sprat larvae.

Biochemical measurements. For biochemical analyses only undamaged larvae were used. The concentration of nucleic acids was measured in 127 individuals using procedures outlined by Clemmesen (1993) and Belchier et al. (2004). Briefly, the amount of DNA and RNA was measured fluorometrically in a microtitre fluorescence reader (Labsystems, Fluorescan Ascent) using the fluorophor ethidium bromide. The DNA content was determined after treatment with RNase (ribonuclease A, Serva). RNA- and DNA concentrations were determined based on calibration curves using lambda DNA and 16S/23S ribosomal RNA (Boehringer Mannheim). The RNA:DNA ratio was used as a proxy for the cells' metabolic activity (Buckley 1984, Clemmesen 1994).

Protein growth rates $\left(\mathrm{Gp}, \% \mathrm{~d}^{-1}\right)$ were then calculated from RNA:DNA and water temperature $\left(T,{ }^{\circ} \mathrm{C}\right)$ using an equation in Buckley (1984) calibrated to Clemmesen's (1993) analytical procedure by dividing RNA:DNA by 1.3 (C. Clemmesen unpubl.):

$$
\mathrm{Gp}=0.93 T+4.75\left(\text { RNA:DNA) }(1.3)^{-1}-18.1\right.
$$

At a given temperature, RNA:DNA and Gp often exhibit a significant decrease after 2 to $4 \mathrm{~d}$ of reduced food intake in larval and post-larval marine fish (Buckley 1984), including sprat (Peck et al. 2004b). The ratio DNA:DW was calculated as a proxy for cell size (response time $<12$ h, Ferron \& Leggett 1994).

The protein content ( $\mu$ g larva ${ }^{-1}$ ) of each larva was determined using the Bio Rad assay, based on the spectrophotometric method of Bradford (1976) and expressed per unit SL. It is expected to increase with improving nutritional condition (Ehrlich 1974, Buckley 1979, Clemmesen 1987). Protein content and DW are positively correlated in larval fish and thus both respond to starvation on the same time scale $(<12 \mathrm{~h}$, Ferron \& Leggett 1994).

Otolith measurements. The sagittae of 61 larvae between 9 and $17 \mathrm{~mm}$ SL were extracted with fine insect needles under a stereomicroscope and fixed in conventional nail polish on a glass slide. The otoliths were magnified (400 to $1000 \times$ ) under a microscope and digital images were taken. A computer image-analysis system (Image Pro 4.5) was used to count the number of rings. Mean daily somatic growth rates (e.g. Fossum et al. 2000) for larvae from 0 to 10 and 65 to $75 \mathrm{~m}$ were calculated as:

$$
\left(\mathrm{SL}-\mathrm{SL}_{1}\right) \times \mathrm{RC}^{-1}
$$

where $\mathrm{SL}_{1}$ is the size at first feeding $(5.5 \mathrm{~mm} \mathrm{SL}$, Shields 1989) when the first otolith rings are formed in sprat (Alshuth 1988), and RC is the ring count (n). Growth rates derived from counts of otolith daily rings integrate the whole lifespan of an individual.

Statistics. Non-parametric Mann-Whitney U-statistics were used to test the null hypothesis of no difference in nutritional condition between top- and bottom-caught sprat larvae. Since multiple comparisons were made, the significance level was adjusted using a modified Bonferroni test (Keppel 1991) across length classes. Differences were considered significant at $\mathrm{p}<0.01$.

\section{RESULTS}

\section{Hydrographic conditions}

Water temperature was highest $\left(14.4^{\circ} \mathrm{C}\right)$ within $10 \mathrm{~m}$ of the surface, decreased rapidly within a thermocline starting at $15 \mathrm{~m}$, and was lowest $\left(4.2^{\circ} \mathrm{C}\right)$ at $40 \mathrm{~m}$. Between 65 and $75 \mathrm{~m}$ the temperature was $7.2^{\circ} \mathrm{C}$. From the surface down to $40 \mathrm{~m}$ salinity remained constant at 7.5 to $8.0 \mathrm{psu}$, then steadily increased to $16.0 \mathrm{psu}$ at the seafloor. The oxygen content declined from $6.8 \mathrm{ml} \mathrm{l}^{-1}$ at the surface to $0.7 \mathrm{ml} \mathrm{l}^{-1}$ at $80 \mathrm{~m}$. Chlorophyll $a$ 
concentration was highest in the top $15 \mathrm{~m}\left(0.95 \mu \mathrm{g} \mathrm{l}^{-1}\right)$ and decreased to $0.16 \mu \mathrm{g} \mathrm{l}^{-1}$ at $60 \mathrm{~m}$. Temperature and chlorophyll a concentration developed similarly with increasing water depth. The strongest stratification was at depths between 60 and $65 \mathrm{~m}$ with a density difference of $1.94 \mathrm{~kg} \mathrm{~m}^{-3}$ (Fig. 1).

\begin{tabular}{ccccccc}
\multicolumn{7}{c}{ Chlorophyll a content $\left(\mu \mathrm{g} \mathrm{I}^{-1}\right)$} \\
0.0 & 0.2 & 0.4 & 0.6 & 0.8 & 1.0 & 1.2
\end{tabular}

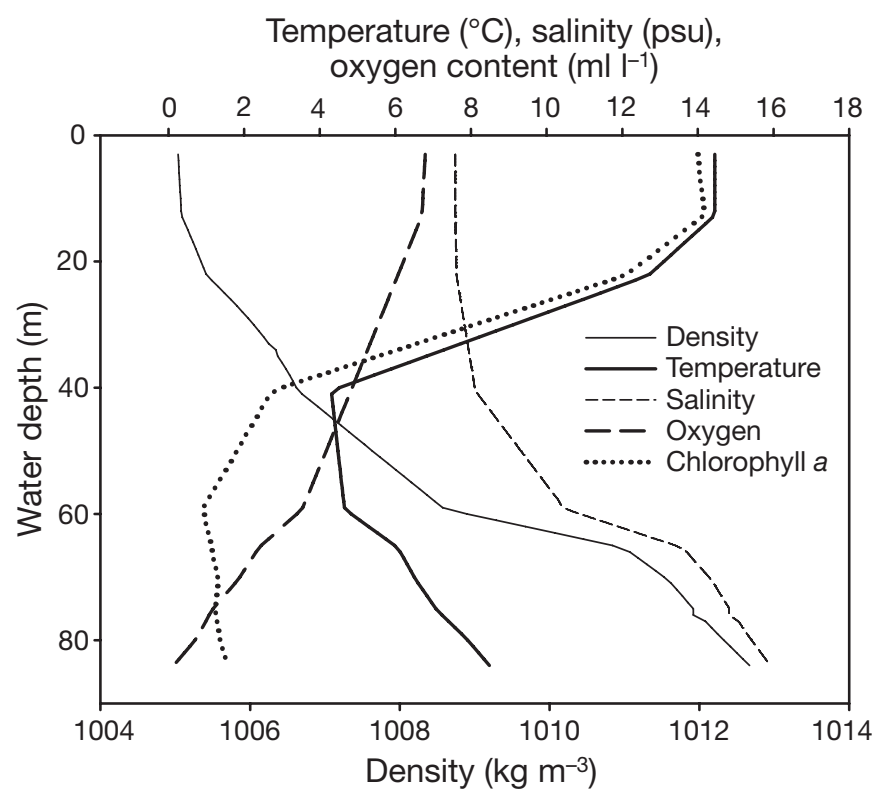

Fig. 1. Vertical profiles of physical variables and chlorophyll a content during collection of larval sprat Sprattus sprattus at 1 sampling station in the Bornholm Basin, Baltic Sea

\section{Vertical distribution}

The density of sprat larvae caught varied among local sampling times and depths. Larval abundance was highest in the upper $10 \mathrm{~m}$ except for 06:00 to 08:00 h and 21:00 to 23:00 h. At each sampling time, a smaller peak in total number occurred at 65 to $75 \mathrm{~m}$ while very few larvae were caught between 45 and $60 \mathrm{~m}$. Abundance peaks were most pronounced during daytime, whereas larval distribution in the water column was more even between dusk and dawn (Fig. 2).

Larvae caught near the surface were longer on average (mean $\pm \mathrm{SD}, 0$ to $10 \mathrm{~m}: 12.1 \pm 2.4 \mathrm{~mm}$ ) than their conspecifics caught at depth (65 to $75 \mathrm{~m}: 9.9 \pm 2.1 \mathrm{~mm}$ ). The longest larvae (>20 mm) occurred in low abundances at $5 \mathrm{~m}$ depth and below the thermocline (Fig. 3).

The cladoceran Bosmina corigoni maritima was the most abundant organism in the plankton samples at all depths (Fig. 4) as well as in larval guts (35\% by number). Larval gut contents appeared to be biased due to the catching procedure and could not be assessed quantitatively. They were excluded from subsequent considerations. During daylight hours, zooplankton occurred at highest concentrations near the surface and had a variable depth distribution below $15 \mathrm{~m}$. At night and in the early morning, the peak in zooplankton near the surface was absent. During the course of the sampling period the concentrations of zooplankton changed by 2 orders of magnitude and was lowest between 00:00 and 08:00 $\mathrm{h}$ and subsequently increased from 09:00 to 20:00 h Central European Summer Time (CEST).

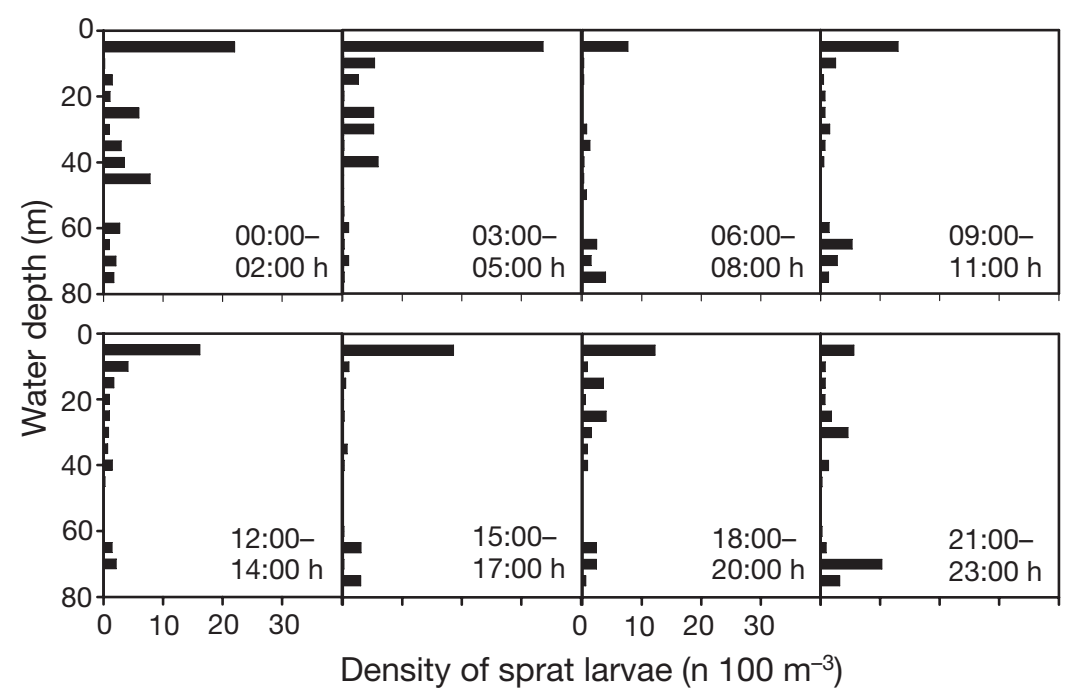

Fig. 2. Sprattus sprattus. Density $\left(\mathrm{n} 100 \mathrm{~m}^{-3}\right.$ ) of sprat larvae (all length classes combined) caught at different times of the day (Central European Summer Time, CEST) at discrete water depths

\section{Morphometric proxies}

For larvae within the length range encountered in sufficient quantities for comparison between shallow and deep samples (8 to $12 \mathrm{~mm} \mathrm{SL})$, larval SL $( \pm \mathrm{SE})$ and DW $( \pm \mathrm{SE})$ were related by:

$\log \mathrm{DW}=3.76( \pm 0.07) \operatorname{logSL}-4.97( \pm 0.07)$

where DW $=\mathrm{mg}$ and $\mathrm{SL}=\mathrm{mm}\left(\mathrm{n}=501, \mathrm{r}^{2}=\right.$ $0.86, \mathrm{p}<0.001)$. Larvae grouped within $1 \mathrm{~mm}$ SL Classes 9, 10, 11 and $12 \mathrm{~mm}$ caught at 65 to $75 \mathrm{~m}$ had statistically significantly higher values of CF (Eq. 2) (range 1.3 to 8.1) than individuals in the same SL classes from 0 to $10 \mathrm{~m}$ (range 0.6 to $7.1, \mathrm{p}<0.01$ ). No statistically significant differences in CF were observed in larvae of SL Class $8 \mathrm{~mm}$. When all SL-classes were pooled, differences between 


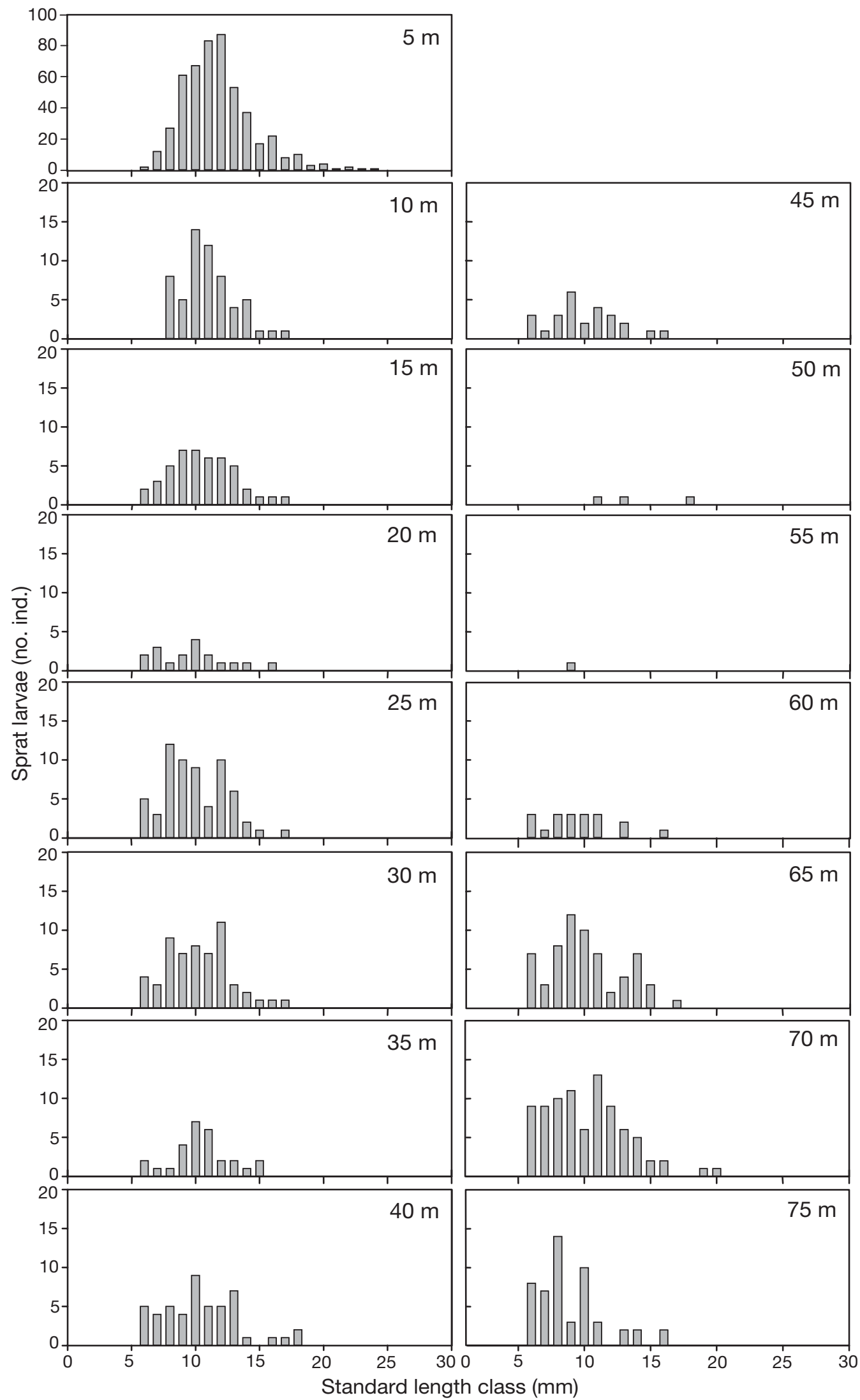

Fig. 3. Sprattus sprattus. Absolute number of sprat larvae caught at different water depths as a function of length class 


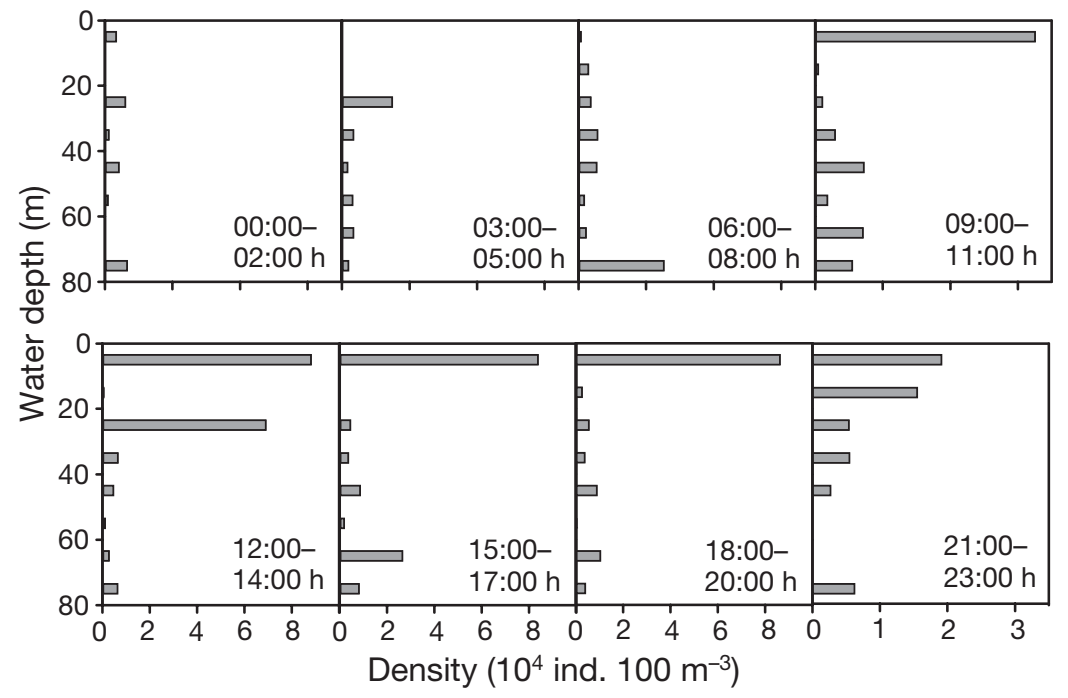

Fig. 4. Bosmina corigoni maritima. Density $\left(\mathrm{n} 100 \mathrm{~m}^{-3}\right)$ at different times of day (CEST) at discrete water depths

top- and bottom-caught larvae remained statistically significant (Fig. 5). CF minima increased with increasing SL only in larvae from a depth of 65 to $75 \mathrm{~m}$. The variability (expressed as the coefficient of variation, CV) of CF decreased steadily with increasing length in larvae caught at 65 to $75 \mathrm{~m}$, while in individuals from 0 to $10 \mathrm{~m}$ no such trend was observed (Fig. 5). Together with protein:SL, the variability of CF was highest among proxies.
Otolith-based somatic growth rates $($ mean $\pm \mathrm{SD})$ were $0.59 \pm 0.19 \mathrm{~mm} \mathrm{~d}^{-1}$ and $0.66 \pm 0.17 \mathrm{~mm} \mathrm{~d}^{-1}$ for larvae sampled at 65 to 75 and 0 to $10 \mathrm{~m}$ depths, respectively. The difference was not significant $(p=$ 0.23). Another commonly used method to calculate otolith-based growth rates, using the slope of the regression of ring count (RC) on SL (e.g. Munk 1993, Rè \& Gonçalves 1993, Valenzuela \& Vargas 2002) yielded lower growth rates (see Table 1). However, using either method, mean daily growth rates between depths were not significantly different.

\section{Biochemical proxies}

The sub-sample of larvae taken for biochemical analyses contained sufficient numbers of larvae of 9 to $12 \mathrm{~mm}$ SL for a comparison between surface and deep samples in each of four 1-mm size classes. In the $10 \mathrm{~mm}$ SL-class RNA:DNA was significantly higher at 0 to $10 \mathrm{~m}$ (p < 0.01). In all other SL-classes no statistically significant difference was noted. When SL-classes 9 to $12 \mathrm{~mm}$ were pooled, differences were not significant. Except for SL $10 \mathrm{~mm}$, the variability (CV) of RNA:DNA in individuals of all length classes caught at 0 to $10 \mathrm{~m}$ was

\begin{tabular}{|c|c|c|c|c|c|c|}
\hline CV & $20 \quad 31$ & 1950 & 2622 & 3218 & 197 & $25 \quad 32$ \\
\hline $\mathrm{n}$ & 2312 & 4711 & $64 \quad 12$ & 8010 & 814 & 29549 \\
\hline p & ns & $<0.01$ & $<0.01$ & $<0.01$ & $<0.01$ & $<0.01$ \\
\hline
\end{tabular}

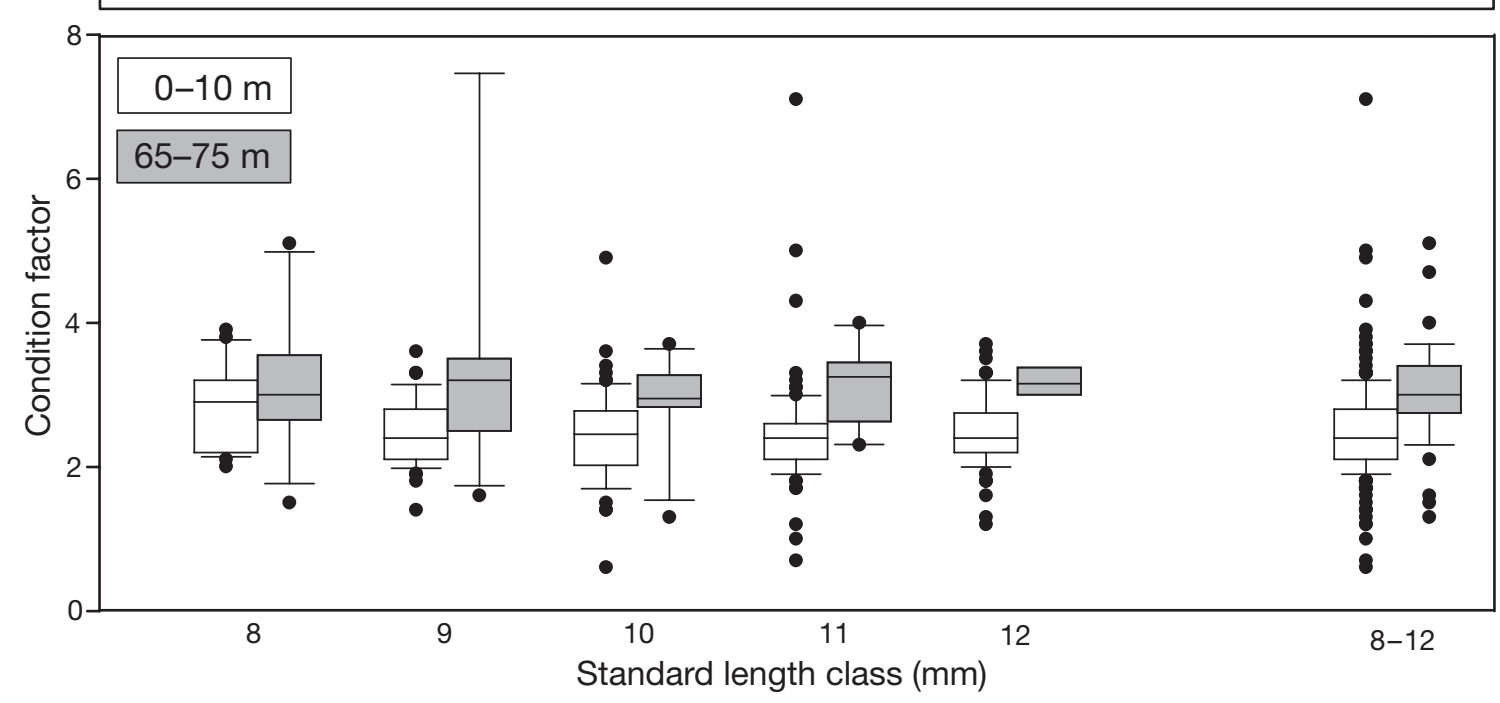

Fig. 5. Sprattus sprattus. Condition factor (CF) of sprat larvae obtained from 0 to 10 and 65 to $75 \mathrm{~m}$, showing median (line), 10 th, 25th, 75th and 90th percentiles and outliers. Variability (CV), sample size (n) and significance level (ns = not significant) are given above each plot 
greater than in those from 65 to $75 \mathrm{~m}$. Clear trends could not be observed in this proxy (Fig. 6).

Following Eq. (3), the Gp of larvae caught at 0 to $10 \mathrm{~m}\left(14.4^{\circ} \mathrm{C}\right)$ was $4.6 \% \mathrm{~d}^{-1}$, compared to $-3.5 \% \mathrm{~d}^{-1}$ (mean daily protein decrease) in individuals caught at 65 to $75 \mathrm{~m}\left(4.2^{\circ} \mathrm{C}\right)$. In all larval length classes, higher values (i.e. lower $R N A$ efficiency) of the Gp were found at 0 to $10 \mathrm{~m}(\mathrm{p}<0.01)$.

Individuals from 65 to $75 \mathrm{~m}$ tended to have smaller cells, as expressed by greater DNA:DW in all the 1-mm SL-classes analysed, in SL-Classes 10 and 11 the differences were statistically significant (Fig. 6, p < 0.003 for 10 and $11 \mathrm{~mm} \mathrm{SL}, \mathrm{p}<0.016$ and 0.046 for 9 and $12 \mathrm{~mm}$ SL). Maximum values were measured only in larvae caught near the seafloor. In all but the 12-mm SL-class, the CV was higher in individuals caught at 0 to $10 \mathrm{~m}$.

The protein content per mm SL was statistically significantly higher at 65 to $75 \mathrm{~m}$ for larvae in the 10, 11 and 12-mm SL classes. In the $9 \mathrm{~mm}$ length class, the relative protein content of larvae was similar at both depths (Fig. 6). As with CF, variability in the protein content per length unit decreased steadily with increasing length in larvae caught at 65 to $75 \mathrm{~m}$, while in individuals from 0 to $10 \mathrm{~m}$ no clear trend could be detected. Together with CF, the variability in protein:SL was the highest among the proxies (Fig. 6).

\section{DISCUSSION}

The survival of marine fish larvae is closely linked to how fast they grow through developmental stages that are particularly vulnerable to mortality via starvation and predation (Houde 1987). Growth rates largely depend on a larva's nutritional state, which can be markedly influenced by changes in food availability and hydrographic features of the environment, especially temperature (Heath 1992). Although there is always a time lag between cause (good or poor feeding conditions) and effect (fast growth or starvation), larval feeding and growth history can be reconstructed from physiological changes resulting from varying environmental conditions (Bergeron \& Boulhic 1994). We measured a variety of commonly applied nutritional proxies in Baltic sprat to construct a more complete picture of whether bimodal depth distributions were associated with differences in larval condition.

\section{Morphometric proxies}

The relationship between weight and length was one of the earliest methods used to assess the condition of larval fish (Shelbourne 1957, Hempel \& Blaxter 1963). It was assumed that greater weight-at-length in- dicated a good nutritional state (e.g. von Westernhagen \& Rosenthal 1981). This assumption was questioned by Ricker (1979), who ascribed a lower weight-at-length to fast-growing individuals, due to the preferential allocation of growth in length as opposed to mass. A lower weight-at-length was correlated to faster growth in juvenile Atlantic cod by Peck et al. (2004a).

In sprat larvae, the CF not only depends upon exogenous conditions (e.g. feeding and temperature) but also upon fish size, since the allometric scaling of mass and length (b, Eq. 2) changes statistically significantly during early ontogeny in this species (Peck et al. 2005). We addressed these uncertainties by comparing only similar size classes between depths. Nevertheless, the CF cannot clearly be interpreted as indicative of fast growth or bad condition and should therefore be viewed only in context with other indices.

The similarity in the otolith-based mean daily growth rates in larvae from both depths in our study suggests that specimen caught at 0 to 10 and 65 to $75 \mathrm{~m}$ were in similar condition, and thus, supports our null hypothesis $\left(H_{0}\right)$, but this proxy integrates conditions experienced over the whole life span of the individual larva and may therefore be fairly insensitive to shortand medium-term effects. For example, a recent bout of starvation would not be represented within this integrated measure. Even though sprat larvae occur over a wide latitudinal range (e.g. Adriatic, Baltic, Irish and North Seas) and within these habitats can encounter diverse environmental conditions (e.g. surface and bottom waters of the Bornholm Basin), otolith-based average daily growth rates appear to change little in this species (Table 1). On the one hand, this observation may suggest the relative insensitivity of this integrative measure to detect changes in sprat condition; on the other hand, the correspondence of otolith-based mean growth rates among different systems for the same species may imply interesting similarities in life history traits of sprat in these different ecosystems. At the present time, evidence for the former and latter is equivocal, and more research is needed.

\section{Biochemical proxies}

The metabolic activity and other vital rates of fish larvae are closely linked to ambient water temperature (e.g. Buckley 1984, MacKenzie \& Köster 2004). One value for RNA:DNA at $14.4^{\circ} \mathrm{C}(0$ to $10 \mathrm{~m}$ ) may indicate good growth potential while the same value at $7.2^{\circ} \mathrm{C}$ (65 to $75 \mathrm{~m}$ ) would suggest slow growth. The minimum RNA:DNA required to maintain metabolism without growth was determined as 1.01 at $14^{\circ} \mathrm{C}$ in postlarval sprat (Peck et al. 2004b). Clemmesen (1994) found 


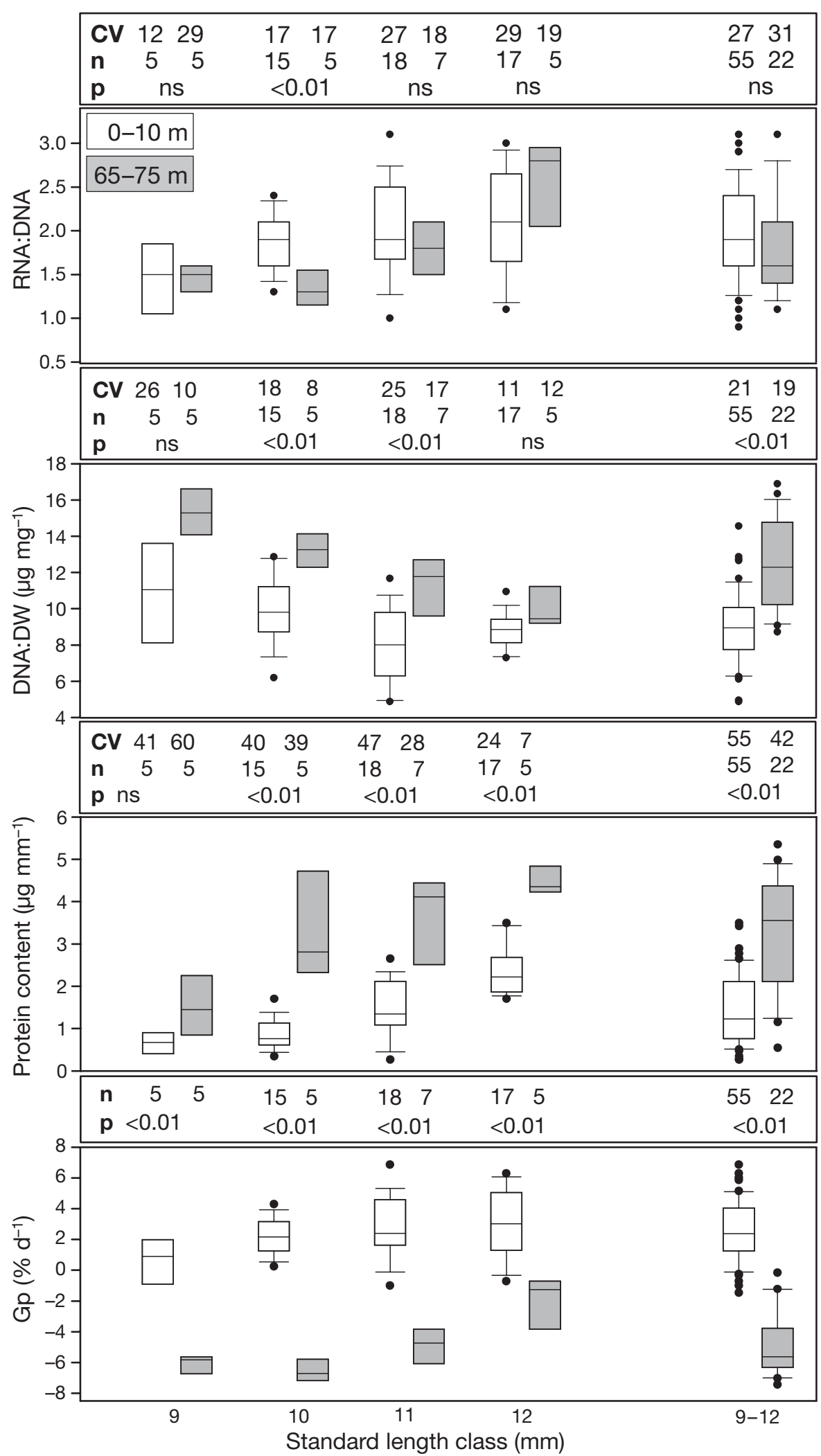

Fig. 6. Sprattus sprattus. Biochemical condition proxies: RNA:DNA, DNA:DW, protein content:SL $\left(\mu g \mathrm{~mm}^{-1}=\mu \mathrm{g} \mathrm{mm} \mathrm{SL}{ }^{-1}\right)$ and daily protein growth rate (Gp) of larval length classes 9, 10, 11 and $12 \mathrm{~mm}$ caught at 0 to 10 and 65 to $75 \mathrm{~m}$ depth, showing median (line), 10th, 25th, 75th and 90th percentiles and outliers. Variability (CV), sample size (n) and significance levels (ns = not significant) are given above each plot. (CV of Gp not shown) 
RNA:DNA values of around 1 to be necessary for survival in starvation experiments performed with larvae of different species reared at 12.0 to $16.7^{\circ} \mathrm{C}$. According to the mean daily protein growth rate Gp (Buckley 1984, and present Eq. 3), these 2 findings suggest that larvae at 0 to $10 \mathrm{~m}$ $\left(14.4^{\circ} \mathrm{C}\right)$ and 65 to $75\left(7.2^{\circ} \mathrm{C}\right)$, would require RNA:DNA values of 0.99 and 2.40 , respectively, to maintain metabolism $(\mathrm{Gp}=0)$. Only $\sim 1 \%$ of the sprat larvae at 0 to $10 \mathrm{~m}$ had an RNA:DNA value $<1.0$, whereas at 65 to $75 \mathrm{~m}$ only $13 \%$ of the larvae had an RNA:DNA value $>2.5$, suggesting a restricted growth potential at the low temperature at these depths.

In contrast, the daily somatic growth rates estimated from otolith microstructure did not show significant differences between depths, which may be explained in 3 ways: (1) larvae caught at 65 to $75 \mathrm{~m}$ could have experienced better growth environments earlier in life, which would be reflected in slow-responding condition proxies such as somatic growth rate rather than by more quickly responding proxies such as RNA:DNA and DNA:DW (2) the larvae may have experienced a continuously changing temperature regime (e.g. through vertical movements of unknown amplitude and frequency, see next subsection) which affected larval physiology in a different manner than the static temperature regime used to calibrate the RNA:DNA - growth relationship presented in the model of Buckley (1984) which (3) may not be directly applicable to sprat.

Despite the good accordance between Gp-values from our study and experimentally derived RNA:DNA minimum values for metabolic maintenance (Clemmesen 1994, Peck et al. 2004b), it remains somewhat problematic to assess larval fish condition using $\mathrm{Gp}$, due to its strong temperature-dependence. Therefore, this proxy should be applied with caution, especially with respect to dynamic temperature regimes that could be encountered by vertically migrating fish larvae.

A proxy less sensitive to the uncertainty imposed by temperature effects is the amount of DNA per unit dry weight, proposed as an indicator for cell size (Bulow 1987) and starvation (Bergeron 1997). Dry weight has been reported to react to food shortage within a few hours, especially in young larvae that have yet to build energy reserves (Ferron \& Leggett 1994). Therefore, the higher DNA:DW ratio in larvae of all length classes at 65 to $75 \mathrm{~m}$ compared to conspecifics captured in surface waters suggests recent starvation at depth.
A lower protein:SL was observed in larvae captured at 0 to $10 \mathrm{~m}$, and is in accordance with the lower $\mathrm{CF}$ (i.e. lower weight-at-length) of individuals from 0 to $10 \mathrm{~m}$ in that high temperatures encountered near the surface may support growth in length of sprat larvae at the expense of the protein content per unit length, which is closely linked to DW (Lied \& Roselund 1984, Bulow 1987). The protein content relative to the body volume of a larva has implications for buoyancy, which is the net result of the lifting forces of water and fat and the sinking forces induced by protein structures (Blaxter \& Ehrlich 1974). Prior to having a functional swim bladder, larvae with high protein contents relative to their body length (as found at 65 to $75 \mathrm{~m}$ ) would require more energy to ascend to and remain in favourable feeding environments, which could be a disadvantage if good feeding conditions are assumed to occur close to the suface.

\section{Vertical distribution}

To put the condition indices we examined into an ecological context it is mandatory to evaluate them with respect to the vertical distribution of the sprat larvae as a function of space and time.

Voss et al. (2005) reported that maximum spawning of sprat eggs occurred in June, $6 \mathrm{wk}$ prior to our sampling efforts in the Bornholm Basin. Eggs were distributed in the upper part of the halocline (typically between 45 and $55 \mathrm{~m}$ ) in the Bornholm Basin. Nissling et al. (2003) found aggregations of sprat eggs between 45 and $60 \mathrm{~m}$ in the same area. The mean specific gravity of eggs decreases during the spawning season, resulting in later-spawned eggs having neutral buoy- 
ancy at shallower depths in contrast to eggs released earlier in the spawning cycle (Nissling et al. 2003). The sprat larvae examined in our study can thus be assumed to have hatched between 40 and $50 \mathrm{~m}$ depth (Fig. 1).

After hatch, sprat larvae perform a first feeding migration into the upper water layers (Voss 2002), which results in maximum concentrations of larvae close to the surface, where prey density and light intensity are greatest and, thus, prey detection and encounter are most likely to be highest (Wieland \& Zuzarte 1991, Voss et al. 2005, this study).

Vertical migration behaviour of different amplitude and temporal patterns has been commonly described for sprat larvae (>6 mm) in the German Bight (Kloppmann 1991) and in the Bornholm Basin (Wieland \& Zuzarte 1991, Voss 2002). Our data revealed diel vertical movements only between the surface and $45 \mathrm{~m}$ (Fig. 2), a depth marking the lower limit of the thermocline (Fig. 1). The limited number of larvae between 45 and $65 \mathrm{~m}$ at all sampling times suggests that individuals caught below the thermocline did not perform vertical movements during our $24 \mathrm{~h}$ data collection. To cross this depth range undetected by depth-specific sampling with a high temporal resolution, an increase in swimming performance or in the vertical:horizontal ratio of effort would be required. An improved swimming performance appears unlikely since the low temperatures between 40 and $60 \mathrm{~m}$ are known to be suboptimal for this species (Nissling 2004). Furthermore, DNA:DW and protein: SL would not have shown clear differences between depths if vertical migrations over the whole water column had regularly occurred.

Alternatively, the abundance minimum of larvae between 45 and $65 \mathrm{~m}$ may also be attributed to increased predation by adult clupeids that were found feeding at this depth (Köster \& Möllmann 1997). Other potential predators (0-group cod and medusae) occur mainly in shallow areas, but were evaluated as negligible sources of larval mortality (Voss et al. 2005).

At most times of the day, except 06:00 to 08:00 and 21:00 to $23: 00 \mathrm{~h}$, the highest numbers of sprat larvae were found close to the surface, whereas density peaks of Bosmina corigoni maritima, the most abundant organism in the zooplankton samples and larval guts, were prominent near the surface only during daylight hours, i.e. the vertical movements of the sprat larvae were not clearly linked to those of their potential prey organisms (Figs. 2 \& 4).

The spatial and temporal extent and the patterns of vertical migration behaviour have been described as a compromise between sufficient light intensity for feeding (e.g. Last 1980, Munk et al. 1989), spatial overlap with prey (e.g. Lough \& Cohen 1982) and predator avoidance (Köster \& Möllmann 1997). Voss (2002) reported a spatial mismatch between Baltic sprat larvae and their prey in 1989 and 1990, and explained this phenomenon with larvae preferring areas of optimal water temperature over high food densities. Our findings support temperature as a key factor determining the vertical distribution and migration behaviour of larval sprat.

The selectivity of a particular environment, such as different depth strata, may become manifest by examining variability within condition indices. While the variability $(\mathrm{CV})$ in condition values was generally higher at 0 to $10 \mathrm{~m}$ than at depth in most length classes, CV values tended to be highest for short-latency proxies (CF and protein:SL) of relatively small larvae caught at depth (Figs. $5 \& 6$ ). Higher variability within condition proxies can denote environments that exert low selective pressure in a relative sense. The CV of shortlatency condition proxies decreased with increasing length in larvae from 65 to $75 \mathrm{~m}$ but not in larvae from shallow waters. Yolk-sac absorption occurs at $5.6 \mathrm{~mm}$ in sprat (Alshuth 1988) and, subsequently, the reliance on exogenous feeding increases with increasing larval length. The relatively low variability in and generally higher median values of condition indices of larger larvae at the surface could either indicate strong selection against individuals in relatively poor condition or a generally favourable environment (so that all members of the population had higher condition values). Given the observed patterns in variability and median condition values, the deep stratum could not be characterised as a favourable growing environments; however, the deep stratum also does not appear to be an area with strong selection against weak individuals.

\section{CONCLUSIONS}

Larval sprat condition was not uniformly expressed by all measures applied to test the hypothesis that nutritional state was similar between shallow and deep waters of the central Bornholm Basin. Sprat larvae from 0 to $10 \mathrm{~m}$ could not be distinguished from conspecifics at 65 to $75 \mathrm{~m}$ using slow (otolith-based daily somatic growth rates) and intermediate responding proxies (RNA:DNA), whereas short-latency proxies (protein:SL and DNA:DW) indicated superior nutritional condition and better (recent) growth of larvae in surface waters. Assessments of a larva's nutritional state using only 1 proxy may thus lead to spurious conclusions. We therefore suggest that a combination of relatively slow-, medium- and fast-responding indicators be implemented, unless sampling periods longer than the response time of all condition proxies (i.e. several days) are utilised and data on cause (good or 
poor feeding conditions) and effect (fast growth or starvation) are available. In particular, for sprat residing in a given habitat, the morphometric condition factor $\mathrm{CF}$ and the daily protein growth rate Gp (Buckley 1984) should be applied with caution and only in addition to more unequivocal condition indices.

It is still unknown if the nutritional condition of the larvae resulted from or in the observed Bimodal depth distribution. At the time of sampling, sprat larvae found at 65 to $75 \mathrm{~m}$ experienced low temperatures that reduced protein growth $(\mathrm{Gp})$, which may have resulted in higher DNA:DW and lower SL:DW (i.e. protein:SL). The depth-dependent differences in these shortlatency proxies suggested that the observed depth distribution could have been a recent phenomenon. At 65 to $75 \mathrm{~m}$, low water temperatures and a concomitant reduction in metabolic rates and other physiological processes would be expected to retain individuals in poor condition.

Successful ascent to the surface would be required for sprat larvae at 65 to $75 \mathrm{~m}$ to return to water layers characterised by warm temperatures, sufficient light, high food and low predator concentrations - conditions favouring growth and survival even in larvae with less than optimal nutritional condition. Larval ascents from 65 to $75 \mathrm{~m}$ were not observed in our study. Directed movements towards deep waters would be highly maladaptive, since these environments render fast growth and survival unlikely. The larvae we observed in the Bornholm Basin's deep strata may be interpreted as a result of a selection against individuals in a poor nutritional state at these depths (Grønkjær et al. 1997, Voss et al. 2005).

Acknowledgements. We thank the crew of RV 'Alkor' for assistance during sampling. Special credit goes to H. Mempel for his strong support with the biochemical analyses. We also thank R. Voss, who provided valuable scientific discussions. We are also grateful to H. Browman, A. Curtis and 2 anonymous reviewers for their comments that have helped to improve the manuscript. This work was funded by the European Union (STORE, grant no. FAIR 98 3959) and by the German Federal Ministry for Education and Research (German GLOBEC).

\section{LITERATURE CITED}

Alshuth S (1988) Daily growth increments on otoliths of laboratory reared sprat, Sprattus sprattus L., larvae. Meeresforschung 32:23-29

Arrhenius F, Hansson S (1993) Food consumption of larval, young and adult herring and sprat in the Baltic Sea. Mar Ecol Prog Ser 96:125-137

Belchier M, Clemmesen C, Cortes L, Doan T and 10 others (2004) Recruitment studies: manual on precision and accuracy of tools. ICES Tech Mar Environ Sci 33:1-35

Bergeron JP (1997) Nucleic acids in ichtyoplankton ecology: a review, with emphasis on recent advances for new per- spectives. J Fish Biol 51:284-302

Bergeron JP, Boulhic M (1994) Rapport ARN/ADN et evaluation de l'etat nutritionnel et de la croissance des larves de poissons marins: un essai de mise au point expérimentale chez la sole (Solea solea L.). ICES J Mar Sci 51: 181-190

Blaxter JHS, Ehrlich KF (1974) Changes in behaviour during starvation of herring and plaice larvae. In: Blaxter JHS (ed) The early life history of fish, Springer-Verlag, Berlin, p 575-588

Bradford M (1976) A rapid and sensitive method for the quantitation of microgram quantities of protein utilizing the principle of protein-dye binding. Anal Biochem 72: 248-254

Buckley LJ (1979) Relationship between RNA-DNA ratio, prey density and growth rate in Atlantic cod (Gadus morhua) larvae. J Fish Res Board Can 36:1497-1502

Buckley LJ (1984) RNA-DNA ratio: an index of larval fish growth in the sea. Mar Biol 80:291-298

Bulow FJ (1987) RNA-DNA ratios as indicators of growth in fish. In: Summerfelt RC, Hall GE (eds) The age and growth of fish. Iowa State University Press, Ames, IA, p 45-64

Clemmesen C (1987) Laboratory studies on RNA:DNA ratios of starved and fed herring (Clupea harengus) and turbot (Scophthalmus maximus) larvae. J Cons Int Explor Mer 43: 122-128

Clemmesen C (1993) Improvements in the fluorometric determination of the RNA and DNA content of individual marine fish larvae. Mar Ecol Prog Ser 100:177-183

Clemmesen C (1994) The effect of food availability, age or size on the RNA/DNA ratio of individually measured herring larvae: laboratory calibration. Mar Biol 118:377-382

Coombs SH, Nichols JH, Conway DVP, Milligan S, Halliday NC (1992) Food availability for sprat larvae in the Irish Sea. J Mar Biol Assoc UK 72:821-834

Cowan JH Jr, Shaw RF (2002) Recruitment. In: Fuiman LA, Werner RE (eds) The unique contribution of early life stages. Blackwell Publishing, Oxford, p 88-111

Cushing DH (1974) The natural regulation of fish populations. In: Harden Jones FE (ed) Sea fisheries research. Elek Science, London, p 399-412

Dulcic J (1998) Larval growth of sprat, Sprattus sprattus phalericus, larvae in the northern Adriatic. Fish Res 36: $117-126$

Ehrlich KF (1974) Chemical changes during growth and starvation of herring larvae. In: Blaxter JHS (ed) The early life history of fish, Springer-Verlag, Berlin, p 301-323

Ferron A, Leggett WC (1994) An appraisal of condition for marine fish larvae. Adv Mar Biol 30:217-303

Fofonoff JGR (1985) Algorithms for computation of fundamental properties of seawater. UNESCO Tech Pap Mar Sci 44:3332-3342

Fossum A, Kalish J, Moksness E (2000) Proceedings from 2nd International Symposium on Fish Otolith Research and Application, Bergen, Norway, 20-25 June 1998. Fish Res 46:1-374

Grønkjær P, Clemmesen C, St John MA (1997) Nutritional condition and vertical distribution of Baltic cod larvae. J Fish Biol 51 (Suppl A):352-369

Heath MR (1992) Field investigations of the early life stages of marine fish. Adv Mar Biol 28:1-174

Hempel G, Blaxter JHS (1963) On the condition of herring larvae. Rapp P-V Réun Cons Int Explor Mer 154:35-40

Houde ED (1987) Fish early life dynamics and recruitment variability. Am Fish Soc Symp 2:17-29

Huwer B (2004) Larval growth of Sardina pilchardus and Sprattus sprattus in relation to frontal systems in the Ger- 
man Bight. Diploma thesis, University of Kiel

ICES (2004) Report of the Baltic Fisheries Assessment Working Group. Int Counc Explor Sea Comm Meet ACFM: 18:1-24

Keppel G (1991) Design and analysis: a researcher's handbook. Prentice-Hall, London

Kloppmann M (1991) Vertical distribution of sprat larvae in the German Bight. Int Counc Explor Sea Comm Meet L:26:1-11

Köster FW, Möllmann C (1997) Predation by sprat and herring on early life stages of cod and sprat in the central Baltic. In: Anonymous (ed) Proceedings of Symposium on Forage Fishes in Marine Ecosystems. Alaska Sea Grant College Program 97-01. University of Alaska, Fairbanks, AK, p 41-70

Köster FW, Möllmann C (2000) Egg cannibalism in Baltic sprat Sprattus sprattus. Mar Ecol Prog Ser 196:269-277

Köster FW, Möllmann C, Neuenfeldt S, St John MA, Plikshs M, Voss R (2001) Developing Baltic cod recruitment models. I. Resolving spatial and temporal dynamics of spawning stock and recruitment for cod, herring, and sprat. Can J Fish Aquat Sci 58:1516-1533

Köster FW, Hinrichsen HH, Schnack D, St. John MA and 7 others (2003) Recruitment of Baltic cod and sprat stocks: identification of critical life stages and incorporation of environmental variability into stock-recruitment relationships. Sci Mar 67 (Suppl 1):129-154

Last JM (1980) The food of twenty species of fish larvae in the west-central North Sea. Fish Res Tech Rep Minist Agric Fish Food Directorate Fish Res 60:1-44

Lied E, Roselund G (1984) The influence of the ratio of protein energy to total energy in the feed on the activity of protein synthesis in vitro, the level of ribosomal RNA and the RNA-DNA ratio in white trunk muscle of Atlantic cod Gadus morhua. Comp Biochem Physiol A 77:489-494

Lough RG, Cohen RE (1982) Vertical distribution of recently hatched herring larvae and associated zooplankton on Jeffreys Ledge and Georges Bank, October 1974. US National Marine Fisheries Service, Northeast Fisheries Science Center, Woods Hole, MA, Ref Doc 82-10

MacKenzie B, Köster FW (2004) Fish production and climate: sprat in the Baltic Sea. Ecology 85:784-794

Matthäus W, Nausch G, Lass HU, Nagel K, Siegel H (2001) The Baltic Sea in 2000-low inflow activity caused an increase in stagnation of the central Baltic deep water. In: Matthäus W, Nausch G (eds) The hydrographic-hydrochemical state of the western and central Baltic Sea in 1999/2000 and during the 1990s. Meereswissenschaftlicher Bericht 45. Leibnitz Institut für Ostseeforschung, Warnemünde, p 89-97

Munk P (1993) Differential growth of larval sprat Sprattus sprattus across a tidal front in the eastern North Sea. Mar Ecol Prog Ser 99:17-27

Munk P, Kiørboe T, Christensen V (1989) Vertical migrations of herring, Clupea harengus, larvae in relation to light and

Editorial responsibility: Howard Browman (Associate Editorin-Chief), Storebø, Norway prey distribution. Environ Biol Fish 26:87-96

Nissling A (2004) Effects of temperature on egg and larval survival of cod (Gadus morhua) and sprat (Sprattus sprattus) in the Baltic Sea - implications for stock development. Hydrobiologia 514:115-123

Nissling A, Müller A, Hinrichsen HH (2003) Specific gravity and vertical distribution of sprat (Sprattus sprattus) eggs in the Baltic Sea. J Fish Biol 63:280-299

Peck MA, Buckley LJ, Bengtson DA (2004a) Inter-individual differences in rates of routine energy loss and growth in young-of-year juvenile Atlantic cod (Gadus morhua). J Fish Biol 64:984-995

Peck MA, Clemmesen C, Baumann H, Herrmann JP, Stäcker S, Temming A (2004b) The growth-feeding relationship in post-larval Baltic sprat (Sprattus sprattus L.): comparison of somatic, nucleic acid- and otolith-based growth rates. Int Counc Explor Sea Comm Meet L:25

Peck MA, Clemmesen C, Herrmann JP (2005) Ontogenic changes of the mass and length relationship in Sprattus sprattus. J Fish Biol 66:882-887

Rè P, Gonçalves E (1993) Growth of sprat Sprattus sprattus larvae in the German Bight (North Sea) as inferred by otolith microstructure. Mar Ecol Prog Ser 96:139-145

Ricker WE (1979) Growth rates and models. In: Hoar WS, Randall DJ, Brett JR (eds) Fish physiology, Vol VIII. Academic Press, New York, p 677-743

Shelbourne JE (1957) The feeding and condition of plaice larvae in good and bad plankton patches. J Mar Biol Assoc UK 36:539-552

Shields RJ (1989) Studies of growth and nutritional status in 0group sprat, Sprattus sprattus (Clupeidae), using otolith microstructure and lipid analysis techniques. PhD thesis, University of Wales, Bangor

Steedman HR (1976) Zooplankton fixation and preservation. Monogr Oceanogr Methodol 4:1-350

Valenzuela GS, Vargas CA (2002) Comparative growth rate of Sprattus sprattus in relation to physical and oceanographic features in the North Sea. Arch Fish Mar Res 49: 213-230

von Westernhagen H, Rosenthal H (1981) On condition factor measurements in Pacific herring larvae. Helgol Meeresunters 34:257-262

Voss R (2002) Recruitment processes in the larval phase: the influence of varying transport on cod and sprat larval survival. PhD thesis, University of Kiel, Germany

Voss R, Clemmesen C, Baumann H, Hinrichsen HH (2005) Baltic sprat larvae: coupling food availability, larval condition and survival. Mar Ecol Prog Ser 308:243-254

Wieland K, Jarre-Teichmann A (1997) Prediction of vertical distribution and ambient development temperature of Baltic cod, Gadus morhua L., eggs. Fish Oceanogr 6:172-187

Wieland K, Zuzarte F (1991) Vertical distribution of cod and sprat eggs and larvae in the Bornholm Basin (Baltic Sea) 1987-1990. Int Counc Explor Sea Comm Meet J:31

Submitted: January 27, 2006; Accepted: November 23, 2006 Proofs received from author(s): June 18, 2007 